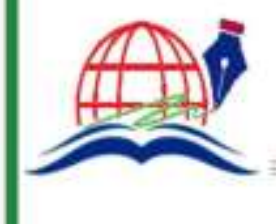

Annals of Spiru Haret University.

Economic Series

Since 2000

ISSN:2393-1795 ISSN-L:2068-6900
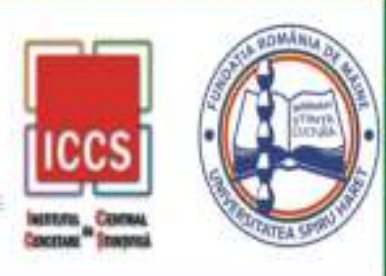

\title{
PERSON-JOB FIT AND EMPLOYEE ENGAGEMENT IN EDO STATE SECRETARIAT, BENIN CITY
}

\author{
Festus OSAYANDE ${ }^{1}$, Ugo Chuks OKOLIE ${ }^{2}$ \\ ${ }^{1}$ Joint Universities Preliminary Examination Board, University of Benin, \\ Benin City, Email: osayandefestus56@gmail.com \\ ${ }^{2}$ Chartered Institute of Personnel Management of Nigeria, Edo State \\ Study Centre, Benin City, Email: ugookolie3@gmail.com
}

How to cite: OSAYANDE, F., \& OKOLIE, U.C. (2019). "Person-Job Fit and Employee Engagement in Edo State Secretariat, Benin City." Annals of Spiru Haret University. Economic Series, 19(4), 43-55, doi: https://doi.org/ $10.26458 / 1933$

\begin{abstract}
In the last four decades, person-job fit, person-organization fit, job related attitudes and behaviours have remained topics of considerable interest in the fields of human resource management, organizational behaviour and industrial psychology. Person-job fit, which is the match between the individual's knowledge, skills and abilities and the demands of the job, positively contributes to organizational attitudes and behaviour such as job satisfaction, job performance, employee's commitment, display of organizational citizenship behaviour and employee's engagement. This study therefore seeks to explore the nitty-gritty of person-job fit and its effect on employee engagement in Edo State Secretariat, Benin City using survey research method. Non-probabilistic sampling techniques comprising of purposeful and convenience techniques were used to elicit information via questionnaire from 250 respondents. Data collected were analyzed using descriptive statistics, correlation and linear regression analysis with the aid of Statistical Package for Social Science (SPSS) version 17. The results of the study showed that there is significant relationship between person-job fit and employee engagement. As predicted, the study also revealed that person-job fit exerts a positive and statistically significant effect on employee engagement. Thus, the study recommends among others that management should emphasize the suitability between job characteristics and employees ability to perform the
\end{abstract}




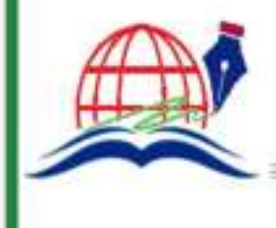

\section{Annals of Spiru Haret University. \\ Economic Series \\ Since 2000}

ISSN:2393-1795 ISSN-L:2068-6900
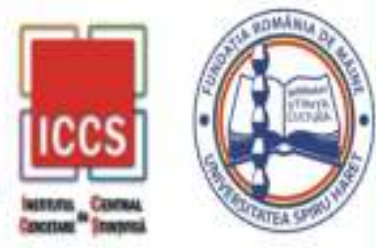

\section{Issue 4/2019}

job. This will go a long way to help employees recognize the similarity among them and thus exchange positive and supportive attitudes and behaviours.

Keywords: person-job fit; employee engagement; intention to stay; attitudes; behaviours.

JEL Classification: M1, M2, M54

\section{Introduction}

In the last four decades, person-job fit, person-organization fit, job related attitudes and behaviours have remained topics of considerable interest in the fields of human resource management, organizational behaviour and industrial psychology. Human resource management plays vital role in developing employees' knowledge, skills, abilities and aptitude to argument their work and organizational performance. The effective functioning of any organization is consisting on the eminence and competence of the employees which are required by the organization to fill its future human resource needs [Hassan et al., 2012]. It is important to note that both practitioners and academicians believe that human capital is the most valuable asset to an organization, the retention of high skilled talent has always been one of the major challenges [Boswell et al., 2008]. It has been noted that high voluntary turnover hinders the strategies objectives of organizations and becomes a severe threat to their competitive advantage [Memon et al., 2015]. Undeniably, the lost of high skilled or talented employees not only creates financial constraints [Jutidi et al., 2013], it also affects the productivity of the organization and low employees' morale [Johnson, 1995]. Despite the severe consequences of voluntary turnover, organizations around the world are constantly facing a high rate of voluntary turnover.

According to Bitzer (2006), the cost incurred in each voluntary movement is equivalent to approximately $25 \%$ to $33 \%$ of the annual salary of each of the employees who quit. Parsa, Tesone and Templeton (2009) affirm that the flaws in the selection process of the organizations could be one of the major reasons for such high rate of voluntary turnover. In a nutshell, it may be possible that selected individuals do not fit in with the organization's environment, and finally, decide to leave that organization for a better fit. Empirical evidence indicates that the existence of fit produces more favourable attitudes - experience, greater well-being and better performance [Kristof-Brown et al., 2005; Jansen \& Kristof-Brown, 2006; Manson \& 


\section{An \\ Annals of Spiru Haret University. \\ Economic Series \\ Since 2000}

ISSN:2393-1795

ISSN-L:2068-6900
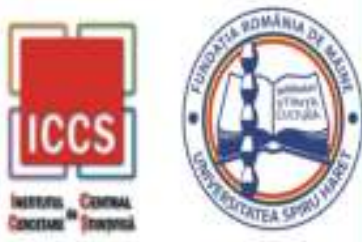

Issue 4/2019

Carr, 2011; Memon et al., 2015]. The literature often indicated two different forms of fit, such as person-job fit and person-organization fit. Person-job fit is defined as compatibility that exists between an individual personal attributes and the job characteristics. Person-job fit has been found to influence various work outcomes such as job satisfaction, job commitment and turnover intention. For instance, person-job fit was found to be positively related to an employee job involvement, job satisfaction, organizational identification and intention to stay [O'Reilly et al., 1991], work stress [Iplik et al., 2011], turnover intention [Boon et al., 2011], organizational and citizenship behaviour and job performance [Cable \& De-Rue, 2002]. A study by Hamid and Yahya (2016) revealed a strong correlation between person-job fit and work engagement.

Unfortunately, only a handful of research in this area has been conducted in Nigeria. This study was undertaken to fill this obvious research gap and we hope to contribute to a better understanding of the effect of person job fit on employee engagement, specifically in the Nigerian context. The main aim of this study is to explore the nitty-gritty of person-job fit and its effect on employee engagement in Edo state secretariat, Benin City using survey research method.

\section{Literature Review}

\section{Employee Engagement}

Engagement is a concept that is hard to define. However, it is easy to realize that concepts of love, trust and justice are crucial for people. In organizations, engagement has become a buzzword [Ridnman, 2006]. The term 'employee engagement' has been conceptualized in a number of ways. It is used as a competitive advantage strategy by human resources of consulting firm [Macey \& Schneider, 2008]. Kahn (1990: 694) defined employee engagement as "the harnessing of organization member's selves to their work roles; people employ and express themselves physically, cognitively and emotionally". Also, it has been defined as "a positive, fulfilling work related state of mind that is characterized by vigour, dedication and absorption" [Schaufeli et al., 2002]. Vigour is characterized by high energy levels, resilience, a desire to strive, and not to give up in the face of challenges. Dedication on the other hand is characterized by feeling of worth, enthusiastic, inspiring, valuable and challenging. While Absorption is characterized by intense concentration, interest and engrossed in the work [Sulistiowati et al., 2018]. Richman (2006) views employee engagement as an emotional and intellectual commitment to the organization. According to Saks (2006:602), employee engagement is "a unique construct composed of cognitive, 


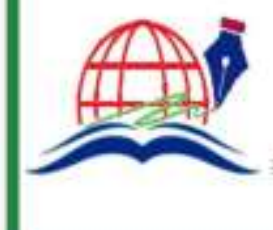

\section{Annals of Spiru Haret University. \\ Economic Series \\ Since 2000}

ISSN:2393-1795 ISSN-L:2068-6900
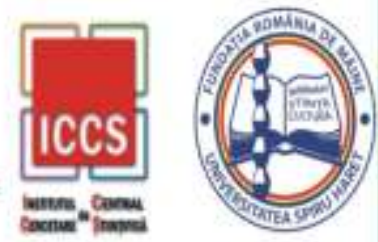

\section{Issue 4/2019}

emotional and behavioural concepts which are related to individual role performance". On the whole, one common agreement in these definitions was the work role of the employee. Therefore, employee engagement in the context of this study can be seen as a multidimensional form of cognitive, emotional and physical interconnected aspects of employees.

Since engagement refers to meaningfulness, safety and availability, it can be expected that a high level of engagement generates positive outcomes such as organizational success and high financial performance [Richman, 2006]. Engaged employees are inclined to increase their job resources (e.g., actively asking for feedback from their supervisor and colleagues) and job demands (e.g., taking the initiative to start a new project) to create a more challenging work environment [Tims et al., 2013]. Bakker and Demerouti (2008) posited that employees with high work engagement will find their work interesting, meaningful and energizing and will experience positive affection, including happiness, joy and enthusiasm. In their study, Schaufeli and Bakkers (2004) found that employees with a high level of engagement are less likely to be involved in turnover behaviour compared to those with low engagement. In addition, an engaged employee will feel loyal and care about the organization's future. This supports the assertion of Azoury, Daou and Sleiaty (2013) who posit that employees who are engaged are builders and loyal to the organization.

\section{Person-Job Fit}

According to Kristof-Brown et al. (2005:284), person-job fit or P-J fit is defined as the "relationship between a person's characteristics and those of the job or tasks that are performed at work". Person-job fit can be interpreted as the fit of the individual's ability with the demand of a job [Edwards, 1991]. This supports the assertion of Leng (2016) who posits that person-job fit is the match between the individual's knowledge, skills and abilities (KSAs) and the demands of the job. Also, Sulistiowati et al. (2018) view person-job fit as the fit between the knowledge, expertise and skills of the employee with a particular job or task. With the fit, it is expected that employees can perform their job without significant constraints. Cable and De-Rue (2002) explained that there are two dimensional approaches to personjob fit, namely Demand-Abilities (D-A) Fit and Need-Supply (N-S) Fit. D-A fit refers to aspects such as the matching between employees' knowledge, skills and abilities (KSAs) with requirements of their jobs. It is the extent to which individual knowledge, skills and abilities meet the demand for work. In the D-A fit approach, it 


\section{in \\ Annals of Spiru Haret University. \\ Economic Series \\ Since 2000}

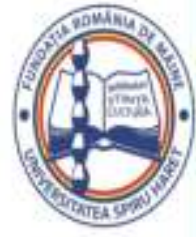

Issue 4/2019

requires knowledge, skills, expertise and other personality's traits to see how well the individual is able to accomplish the task of his/her job [Sulistiowati et al., 2018]. While N-S fit refers to the extent to which employees needs, aspirations and preferences are fulfilled by the jobs they perform and by the rewards associated with that jobs [Cable \& De-Rue, 2002]. A good fit exists when an individual has the right knowledge, skills and abilities to perform his/her job or the job can fulfil the individual's need [Edwards, 1991].

\section{Theoretical Framework}

While there are several theories which might prove appropriate for a discourse of this nature, the personality-job fit theory and the theory of work adjustment present us with a heuristic tool for interrogating the central issues of the study. The effort to match job requirements with personality characteristics is best articulated in Holland's (1997) personality-job fit theory. The theory identifies six personality types and proposes that the fit between personality type and occupational environment determines satisfaction and turnover. That is, satisfaction and the propensity to leave an organization depend on the degree to which individuals successfully match their personalities to a job as shown in the model below.

The theory argues that satisfaction is highest and turnover is lowest when personality and occupation is in agreement. Social individuals should be in social jobs, conventional people in conventional jobs, and so forth. A realistic person in a realistic job is in a more congruent situation than a realistic person in an investigative job. A realistic person in a social job is in the most incongruent situation. The key points of this model are that (1) there appear to be intrinsic differences in personality among individuals, (2) there are different types of jobs, and (3) people in jobs congruent with their personality should be more satisfied and less likely to voluntarily resign than people in incongruent jobs. The theory of work adjustment development by Dawis, England and Lofquist (1968), on the other hand, explained that the closer the correspondence of an individual's knowledge, skills and abilities (KSAs) with the requirements of the job role or organization, the higher the likelihood that the individual will be engage and perform the job better. For instance, in a marketing profession, employees are required to listen to unruly customers (e.g., Agreeableness), and making sales calls (e.g., extraversion). Hence, it is expected that employees who are able to relate to the tasks positively are more likely to be more comfortable performing the tasks and to remain in their job. As noted before, 


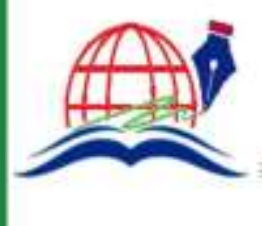

\section{Annals of Spiru Haret University. \\ Economic Series \\ Since 2000}

ISSN:2393-1795 ISSN-L:2068-6900

\section{Issue 4/2019}

engaged employees are in positive, fulfilling affective-motivational states. To achieve consistency between the experienced positive affect and their feelings of person job fit, engaged workers might be motivated to change the components of the workplace environment [Yu, 2009]. According to Scroggins (2008), in the self-concept-job fit, employees are more likely to adjust themselves to fit with their job requirements. Maslach and Leiter (2008), drawing from the personality-job fit theory, stressed that the greater the perceived congruity, the greater the likelihood of engagement with work. In the final analysis, the relevance of the personality-job fit theory and the theory of work adjustment is based on their ability to justify how person-job fit influence employee engagement and intention to stay or leave an organization.

\begin{tabular}{|l|l|l|}
\hline \multicolumn{3}{|c|}{ Holland's Typology of Personality and Congruent Occupations } \\
\hline \multicolumn{1}{|c|}{ Type } & \multicolumn{1}{|c|}{$\begin{array}{c}\text { Personality } \\
\text { Characteristics }\end{array}$} & \multicolumn{1}{c|}{ Congruent Occupations } \\
\hline $\begin{array}{l}\text { Realistic: } \text { prefers physical } \\
\text { activities that require skill, } \\
\text { strength and coordination }\end{array}$ & $\begin{array}{l}\text { Shy, genuine, persistent, } \\
\text { stable, conforming and } \\
\text { practical }\end{array}$ & $\begin{array}{l}\text { Mechanic, drill press } \\
\text { operator, assembly-line } \\
\text { worker and farmer }\end{array}$ \\
\hline $\begin{array}{l}\text { Investigative: } \text { prefers activities } \\
\text { that involve thinking, organizing } \\
\text { and understanding }\end{array}$ & $\begin{array}{l}\text { Analytical, original, } \\
\text { curious and independent }\end{array}$ & $\begin{array}{l}\text { Biologist, economist, } \\
\text { mathematician and news } \\
\text { reporter }\end{array}$ \\
\hline $\begin{array}{l}\text { Social: prefers activities that } \\
\text { involve helping and developing } \\
\text { others }\end{array}$ & $\begin{array}{l}\text { Sociable, friendly, } \\
\text { cooperative and } \\
\text { understanding }\end{array}$ & $\begin{array}{l}\text { Social worker, teacher, } \\
\text { counsellor and clinical } \\
\text { psychologist }\end{array}$ \\
\hline $\begin{array}{l}\text { Conventional: prefers rule } \\
\text { regulated, orderly and } \\
\text { unambiguous activities }\end{array}$ & $\begin{array}{l}\text { Conforming, efficient, } \\
\text { practical, unimaginative } \\
\text { and inflexible }\end{array}$ & $\begin{array}{l}\text { Accountant, corporate } \\
\text { manager, bank teller, file } \\
\text { clerk etc. }\end{array}$ \\
\hline $\begin{array}{l}\text { Enterprising: prefers verbal } \\
\text { activities in which there are } \\
\text { opportunities to influence other } \\
\text { and attain power. }\end{array}$ & $\begin{array}{l}\text { Self-confident, } \\
\text { ambitious, energetic and } \\
\text { domineering }\end{array}$ & $\begin{array}{l}\text { Lawyer, real estate agent, } \\
\text { public relations specialist } \\
\text { and small business manager }\end{array}$ \\
\hline $\begin{array}{l}\text { Artistic: } \text { prefers ambiguous and } \\
\text { unsystematic activities that } \\
\text { allow creative expression }\end{array}$ & $\begin{array}{l}\text { Imaginative, disorderly, } \\
\text { idealistic, emotional and } \\
\text { impractical }\end{array}$ & $\begin{array}{l}\text { Painter, musician, writer } \\
\text { and interior decorator. }\end{array}$ \\
\hline
\end{tabular}

Source: Adopt from John Holland's personality-job fit theory, 1997 


\section{in \\ Annals of Spiru Haret University. \\ Economic Series \\ Since 2000}

ISSN:2393-1795 ISSN-L:2068-6900
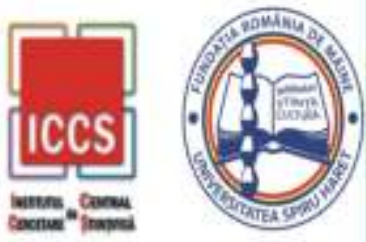

Issue 4/2019

\section{Person-Job Fit and Employee Engagement}

An employee's psychological condition plays an important role in employee engagement with his job [May et al., 2004]. One of the psychological conditions is the person-job fit [Juhdi et al., 2013]. Employees who are better fitted in their organizations are engaged, committed and want to remain part of the organization but will prefer changing their job positions if they are not fitted with their jobs [Saks \& Ashforth, 1997]. Warr and Inceoglu (2012) stressed that a poor level of person-job fit is expected to be linked with low engagement. Hollenbeck (1989) conducted an empirical study and concluded that poor person-job fit will result in job turnover. This supports the assertion of Wilk and Sackett (1996) who posited that individuals who experience a mis-fit between their own abilities and complexities of the job will have an intention to leave their job for another job in which they perceive better fit. Increased productivity, job satisfaction, job commitment, job engagement and reduced turnover intention becomes apparent as the congruence between an individual and a job increases [Iplik et al., 2011]. Individuals who are fit with their job will feel confident with the work they do, more confidently with their roles in the job and tend to be engaged with their job [Saks \& Gruman, 2011; Memon et al., 2015]. In their study, Hamid and Yahya (2016) found that there is a strong and significant relationship between person-job fit and work engagement. Also, Sulistiowati et al. (2018) study in higher education institutions in Indonesia revealed that person-job fit has a positive and significant relationship with employee engagement. In addition, the study conducted by Manson and Carr (2011) classified person-job fit into three categories, namely, demands-abilities fit, supplies-value fit and perceived fit. The three categories of the person-job fit are tested for their influence on three main job related outcomes, namely, job satisfaction, work engagement and life satisfaction. Overall, they found that person-job fit exerts a positive effect on the three job related outcomes. Specifically, the study conducted by Sulistiowati et al. (2018) revealed that person-job fit exerts a positive and statistically significant effect on employee engagement.

In line with the literature review, the following objectives and hypotheses were formulated for the study:

i. To examine the relationship between person-job fit and employee engagement in Edo state secretariat, Benin City.

ii. To assess the effect of person-job fit on employee engagement in Edo state secretariat, Benin City. 


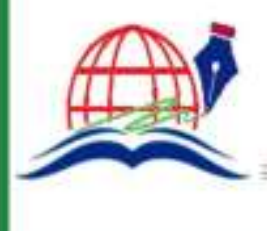

\section{Annals of Spiru Haret University. \\ Economic Series \\ Since 2000}

ISSN:2393-1795 ISSN-L:2068-6900

\section{Issue 4/2019}

Hypotheses of the Study:

$\mathrm{H}_{1}$ : There is no significant relationship between person-job fit and employee engagement in Edo state secretariat, Benin City.

$\mathrm{H}_{2}$ : Person-job fit does not have a significant effect on employee engagement in Edo state secretariat, Benin City.

\section{Methodology}

The study adopted a survey research design to determine the effect of person-job fit on employee engagement in Edo state secretariat, Benin City. Data was collected via a survey of 250 respondents using non-probabilistic sampling techniques comprising of purposeful and convenience techniques. The research instrument used for this study was the structured questionnaire. This was a modified form of the research instrument used by Schaufeli, Bakker and Salonova (2006); Cable and DeRue (2002) and Lauver and Kristof-Brown (2001). This was necessary to better address the new respondents in a different environment. Out of the 250 copies of questionnaire administered, 217 were retrieved and analyzed giving us a response rate of $86.8 \%$. Out of the 217 respondents, 98 were female staff and 119 were male staff. The items of measurement were rated on 5-point like type of scale which ranks responses on a scale of (1) strongly disagreed to (5) strongly agreed. Data collected were tested and analyzed using descriptive, correlation and linear regression analysis. A pilot study to determine the level of reliability was carried out on 50 staff that was part of the study within three weeks. Cronbach Alpha method was used to establish the internal consistency of the instrument as shown in the table below.

Table 1. Reliability Test

\begin{tabular}{|l|l|l|}
\hline Scale & No of items & Cronbach's Alpha \\
\hline Person-job fit & 7 & 0.921 \\
\hline Employee engagement & 9 & 0.877 \\
\hline
\end{tabular}

The results yield a coefficient of 0.921 and 0.877 , which satisfied the general recommended level of 0.70 for the research indicators [Cronbach, 1951]. Also, the questionnaire was validated by experts in management sciences. Hence, researchers' satisfied both reliability and validity of the scale. 


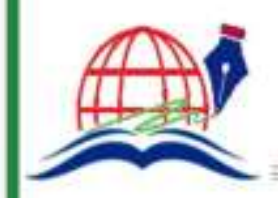

\section{Annals of Spiru Haret University.}

Economic Series

Since 2000

ISSN:2393-1795 ISSN-L:2068-6900

Issue 4/2019

Data Analysis and Results

Table 2. Descriptive Statistics and Correlation Matrix

\begin{tabular}{|l|lc|c|}
\hline Variables & $\begin{array}{l}\text { Mean } \\
\text { Deviation }\end{array}$ & Standard & 1 \\
\hline 1. Person-job fit & 3.491 & 0.635 & \\
\hline 2. Employee engagement & 3.075 & 0.687 & 0.896 \\
\hline
\end{tabular}

$* *$ Correlation is significant at 0.01 levels (2-tailed)

Table 2 shows the mean values, standard deviations and correlation coefficient between both the dependent and independent variables. There exists a significant positive high correlation between person-job fit and employee engagement $(\mathrm{r}=$ $0.896, \mathrm{n}=217, \mathrm{p}<0.01)$. This implies that person-job fit has a strong and positive relationship with employee engagement. Therefore, the null hypothesis is rejected.

Linear Regression Analysis

\section{Table 3. Model Summary b}

\begin{tabular}{|l|l|l|l|l|}
\hline Model & $\mathrm{R}$ & $\mathrm{R}^{2}$ & Adj-R & Std. Error of the Estimate \\
\hline 1 & 0.668 & 0631 & 0.574 & 0.235 \\
\hline
\end{tabular}

a. Predictors: (constant), person-job fit

b. Dependent variable: Employee engagement

Table 4. ANOVA

\begin{tabular}{|l|l|l|l|l|l|l|}
\hline Model & $\begin{array}{l}\text { Sum of } \\
\text { Square }\end{array}$ & Df & Mean & F. & Sig. & Remark \\
\hline Regression & 16.548 & 3 & 4.182 & 32.185 & 0.003 & Sig \\
\hline Residual & 10.291 & 211 & 0.263 & & & \\
\hline Total & 26.839 & 214 & & & & \\
\hline
\end{tabular}

a. Dependent variable: Employee engagement

b. Predictors: (constant), Person-job fit

The linear regression shows $\left(\mathrm{R}^{2}\right)$ value of 0.631 which reveals that person-job fit independently accounts for $63.1 \%$ of the variation in employee engagement in Edo 


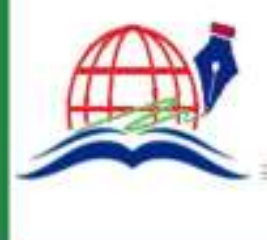

\section{Annals of Spiru Haret University. \\ Economic Series \\ Since 2000}

ISSN:2393-1795 ISSN-L:2068-6900

\section{Issue 4/2019}

state secretariat, Benin City. The F. Statistics of 32.185 revealed that the model is statistically significant at 0.05 significant levels. Therefore, the null hypothesis is rejected.

\section{Discussion}

The results among others showed that person-job fit has strong and positive correlation with employee engagement. This finding is in agreement with previous studies. Hollenbeck (1989); Manson and Carr (2011); Hamid and Yahya (2016); Sulistiowati et al. (2018) found that person-job fit has a positive relationship with employee engagement. The finding also support the views of Memon et al. (2015) that individuals who are fit with their job will feel confident with the work they do, more confidently with their roles in the job and tend to be engaged with their job. Also, based on the results of regression analysis, person-job fit has significantly explained $63.1 \%$ of variation in employee engagement in Edo state secretariat, Benin City. Therefore, the study has shown that person-job fit exerts a positive and statistically significant effect on employee engagement. This finding corroborates Memon et al. (2015), Unal and Turgut (2015); Hamid and Yahya (2016); Sulistiowati et al. (2018) who reported that person-job fit exerts a positive effect on employee engagement. The finding is also in agreement with the views of Maslach and Leiter (2008) that the greater the perceived congruity, the greater the likelihood of engagement with work.

\section{Conclusion and Recommendations}

The study has revealed through its perceived findings that person-job fit has a positive effect on employee engagement. Therefore, person-job fit plays an important role for employees to be engaged and engagement has a negative association with turnover intention. Also, the relationship between person-job fit and employee engagement was confirmed. Thus, the greater the perceive congruity, the greater the likelihood of employee engagement in an organization. Based on the research findings, the study recommends as follows:

i. Management should emphasize the suitability between job characteristics and employees ability to perform the job. This will go a long way to help employees recognize the similarity among them and thus exchange positive and supportive attitudes and behaviours. 


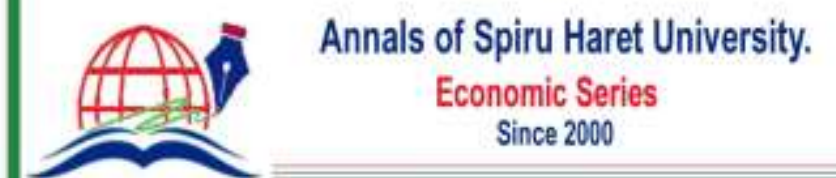

ISSN:2393-1795 ISSN-L:2068-6900
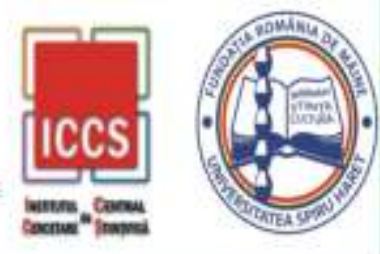

Issue 4/2019

ii. Management should provide employees more job autonomy and create a more relaxed work environment. This could help employees tailor their jobs to fit their motives, strengths and passions.

iii. The study also suggested that further empirical work should be conducted on a larger sample using employees in private hospital in Edo state.

iv. Further studies should be conducted to test other behavioural constructs, especially organizational citizenship behaviour, as a mediator between person-job fit and turnover intention.

\section{References}

[1] Azoury, A., Daou, L. \& Sleiaty, F. (2013). "Employee engagement in family and nonfamily firms." International Strategic Management Review, 1(1-2), 11-29.

[2] Bakker, A.B., \& Demerouti, E. (2008). "The job demands - resources model: State of the art." Journal of managerial Psychology, 22, 309-328.

[3] Bitzer, E. (2006). "Strategies for cutting turnover." Security Management, 50 (5), 8892.

[4] Boon, C., Den-Hartog, D.N., Boselie, P. \& Paauwe, J, (2011). "The relationship employee job change and job satisfaction: The honeymoon-hangover effect." Journal of Applied Psychology, 90, 882-982.

[5] Boswell, W.R., Ren, L.R. \& Hinrichs, A.T. Voluntary employee turnover: Determinants, processes, and future directions. London: Sage publishers, 2008.

[6] Cable, D.M. \& De-Rue, D.S. (2000). "The convergent and discriminate validity of subjective fit perceptions." Journal of Applied Pychology, 87, 875-884.

[7] Dawis, R.V., Engliand, J.D.W., \& Lofquist, L. H. (1968). A theory of work adjustment: A revision. Retrieved from http://vpr.psych.umn.edu/assets.pdf.

[8] Edwards, J.R. (1991). Person-job fit: A conceptual integration, literature review and methodological critique. New York: Wiley Publishers.

[9] Hamid, S.N.A. \& Yahya, K.K. (2016). "Mediating role of work engagement on the relationship between person-job fit and employees' retention: Evidence from semiconductor companies in northern region of Malaysia." International Review of Management and Marketing, 6(57), 187-194.

[10] Hassan, M.U., Akram, A. \& Naz, S. (2012). "The relationship between personorganization fit, person-job fit and turnover intention in banking sector of Pakistan: The mediating role of psychosocial climate." International Journal of Human Resource Studies, 2 (3), 172-188. 


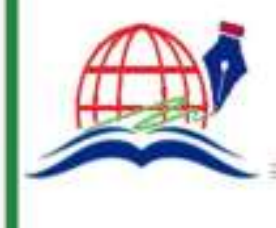

\section{Annals of Spiru Haret University. \\ Economic Series \\ Since 2000}

ISSN:2393-1795 ISSN-L:2068-6900

\section{Issue 4/2019}

[11] Hollenbeck, J.R. (1989). "Control theory and the perception of work environments: The effects of focus of attention on affective and behavioural reactions to work." Organizational Behaviour and Human Process, 43 (3), 406-430.

[12] Iplik, F.N., Kilic, K.C. \& Valcin, A. (2011). "The simultaneous effects of person organization and person - job fit on Turkish hotel managers." International Journal of Contemporary Hospitality Management, 25 (2) 1-41.

[13] Jansen, K.J. \& Kristof-Brown, A.L. (2006). "Toward a multidimensional theory of person-environment fit." Journal of Managerial Issues, 18, 193-212.

[14] Johnson, A. (1995). "The business case for work - family programs." Journal of Accountancy, 180 (2), 53-59.

[15] Juhdi, N. Pa'wan, F., \& Hansaram, R.K.M. (2013). "HR practices and turnover intention: The mediating roles of organizational commitment and organizational engagement in a selected region in Malaysia." The International Journal of Human Resource Management, 24 (15), 3002-3019.

[16] Kahn, W.A. (1990). "Psychological conditions of personal engagement and disengagement at work." Academy of Management Journal, 33, 692-724.

[17] Kristof-Brown, A.L., Zimmerman, R.D., \& Johnson, E.C. (2005). "Consequences of individuals' fit at work: A meta-analysis of person-job, person-organization, persongroup and peron-supervisor fit." Personnel psychology, 58 (2), 281-342.

[18] Lauver, K.J. \& Kristof-Brown, A. (2001). "Distinguishing between employee perceptions of person-job fit and person-organization fit." Journal of Management Studies, 8(2), 157-179.

[19] Leng, G.E. (2016). "Person-job fit, personality, organizational commitment and intention to stay among employees in marketing departments." Jurnal Psikologi, Malaysia, 30 (1), 80-89.

[20] Macey, W.H. \& Schneider, B. (2008). "The meaning of employee engagement." Industrial and Organizational Psychology, 1, 3-30.

[21] Manson, J.M. \& Carr, S.C. (2011). "Improving job fit for mission workers by including expatriate and local job experts in job specification." Journal of Managerial Psychology, 26 (6), 465-484.

[22] Maslach, C. \& Leiter, M.P. (2008). "Early Predictors of job burnout and engagement." Journal of Applied Psychology, 93, 498-512.

[23] Memon, M.A., Salleh, R. \& Baharom, M.N.R. (2015). "Linking person-job fit, personorganization fit, employee engagement and turnover intention: A three-step conceptual model." Asia Social Science, 11 (2), 313-320.

[24] O' Reilly, C.A., Chatman, J. \& Caldwell, D.F. (1991). "People and organizational culture: A profile comparison approach to assessing person-organization fit." Academy of Management journal, 34 (3), 487-526. 


\section{急 \\ Annals of Spiru Haret University. \\ Economic Series \\ Since 2000}

[25] Parsa, H.G. Tesone, D. \& Templeton, A. (2009). “All employees are not created equal: An alternative method of assessing employee turnover." Journal of Foodservice Business Research, 12, 317-330.

[26] Richman, A. (2006). "Everyone wants an engaged workforce how can you create it?" Workspan, 49, 36-39.

[27] Saks, A.M. \& Ashforth, B.E. (1997). "A longitudinal investigation of the relationship between job information sources, applicant perceptions of fit and work outcome." Personnel Psychology, 50 (2), 395-426.

[28] Saks, A.M. \& Gruman, J.A. (2011). "Getting newcomers engaged: the role of socialization tactics." Journal of Managerial Psychology, 26, 383-402.

[29] Saks, A.M. (2006). "Antecedents and consequences of employee engagement." Journal of Managerial Psychology, 21 (7), 600-619.

[30] Schaufeli, W.B. \& Bakker, A.B. (2004). "Job demands, job resources and their relationship with burnout and engagement: A multi-sample study." Journal of Organizational Behaviour, 25, 293-315.

[31] Schaufeli, W.B., Bakker, A.B. \& Salanova, M. (2006). "The measurement of work engagement with a brief questionnaire: A cross-national study." Educational and Psychological Measurement, 66, 701-716.

[32] Schaufeli, W.B., Salanova, M. Gonzalez-Roma, V., \& Bakker, A.B. (2002). "The measurement of engagement and burnout: A two sample confirmatory factor analytic approach.” Journal of Happiness Studies, 3, 71-92.

[33] Scroggins, W.A. (2008). "Antecedents and outcomes of experienced meaningful work: A person-job fit perspective." Journal of Business Inquiry, 7, 68-78.

[34] Sulistiowati, S., Komari, N. \& Dhamayanti, E. (2018). "The effects of person-job fit on employee engagement among lecturers in higher education institutions. Is there a difference between lecturers in public and private higher education institutions?" International Review of Management and Marketing, 8 (3), 75-80.

[35] Tims, M., Bakker, A.B. \& Derks, D. (2013). "The impact of job crafting on job demands, job resources and well-being." Journal of Occupational Health Psychology, $18,230-240$.

[36] Unal, Z.M. \& Turgut, T. (2015). “The buzzword: Does person-organization fit contribute to employee engagement?" Iranian Journal of Management Studies, 8(2), 157-179.

[37] Warr, P. \& Inceoglu, I. (2012). "Job engagement, job satisfaction and contrasting associations with person-job fit." Journal of Occupational Health Psychology, 17 (2), 129-138.

[38] Wilk, S.L. \& Sackett, P.R. (1996). "Longitudinal analysis of ability - job complexity fit and job change." Personnel Psychology, 49 (4), 937-967. 
Annals of Spiru Haret University. 